\title{
The Fall of the Ravens
}

by Maurice G. Street, Nipawin, Sask.

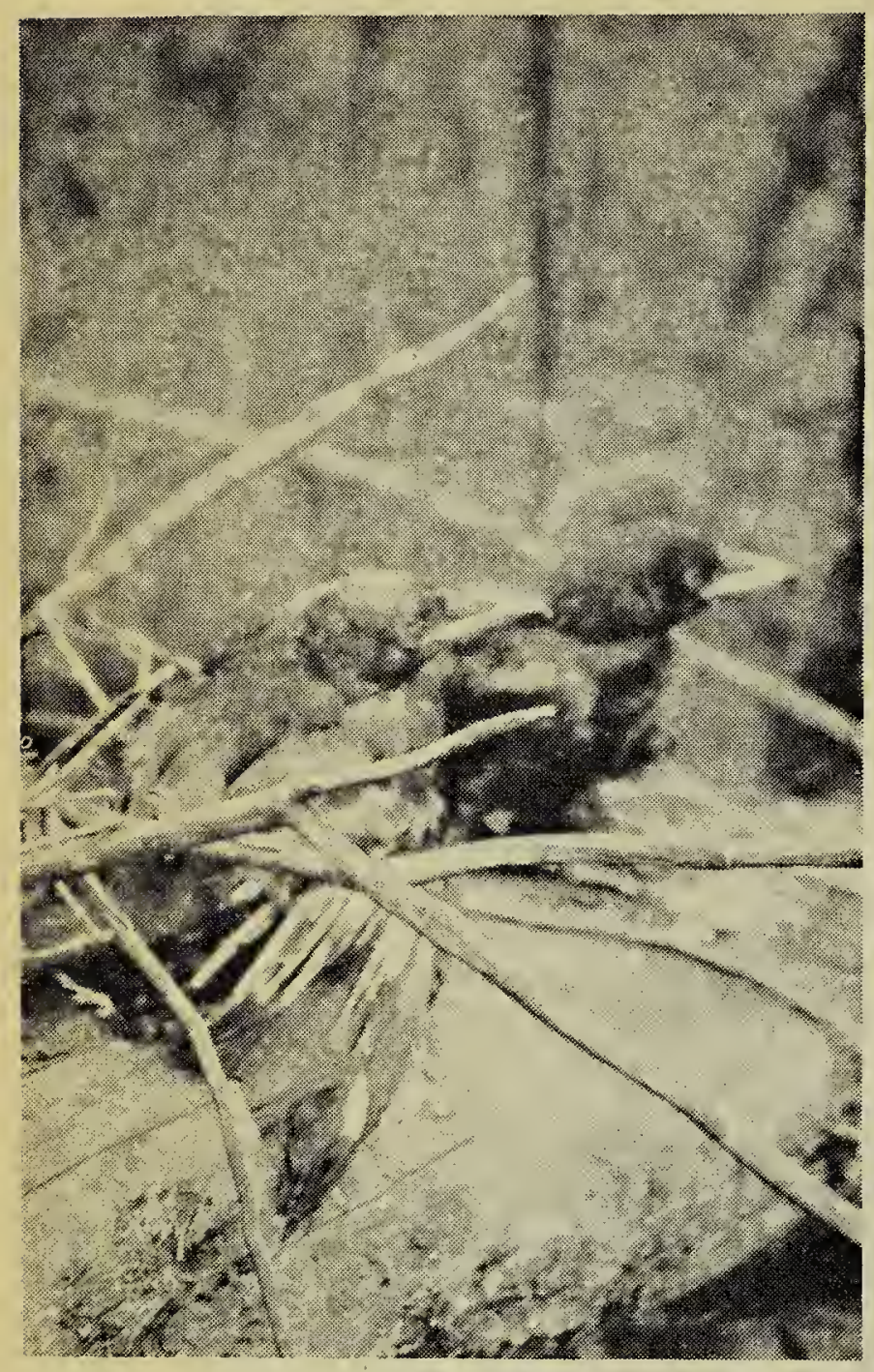

Ycung Ravens at Nipawin, May 10, 1959.

A pair of Common Ravens have built their nest each year since 1953 in tall trees growing in a deep ravine $11 / 2$ miles south of Nipawin. This ravine is about $1 / 2$ mile long and about 200 yards wide at its widest and is well over 100 feet in depth. Both white and black poplar, white spruce, and considerable stands of birch clothe its sides and bottom, along which flows a spring-fed stream two feet wide and several inches deep, summer and winter.

Here the ravens, probably the same pair, build their nests in a huge black poplar growing from the ravine floor. These black poplars are branchless up to 35 feet or more and their girth makes them almost impossible to climb without special equipment. The ravens nest very early, long before the snow begins to thaw, and the young have usually left their nest before the middle of May. On May 10 this spring, on a visit to this ravine, I discovered that their nest, which had been built on top of their 1957 nest (not used in 1958) had fallen out of the tree. The cause of this I do not know-perhaps it was due to high winds, or to the accumulated weight of the old and the new nest plus the weight of the young. Two dead young were found in the tangled mass of sticks that had fallen well over 40 feet. These were about half grown. However, the adults were still present and showed much concern while I made my way down into the ravine and when I was examining the fallen nest. So a search for young that might have survived the fall was begun. A tangled mass of fallen trees and thick bushes made searching very difficult. About 30 feet from the nest an adult, I think the female, alighted on a branch a few feet above me and hammered her beak repeatedly on the branch in on uncertain manner. And almost at my feet I found the first of four fully-feathered young. The other three were found at distances up to 100 feet from the fallen nest. All four were banded with Fish and Wildlife Service bands, and are, I believe, the first nestling ravens to be banded in Saskatchewan.

\section{S.N.H.S. CHRISTMAS CARDS AND CALENDARS}

CHRISTMAS CARDS (folder-type 4" $x$ 5"): Two designs-(1) Black-and-white photo of Snowy Owl by Cy Hampson, Edmonton; (2) Kodachrome photo of Boggy Creek by R. W. Fyfe (1958 cardlimited number). Price- $\$ 1.00$ per doz.

HASTI-NOTES (folder-type $4^{\prime \prime}$ x $5^{\prime \prime}$ ): Kodachrome of Western Red Lily by F. W. Robinson (1958 card). Price $\$ 1.00$ per doz.

CALENDARS 1960: Coloured reproduction (6" $\left.x 9^{\prime \prime}\right)$ of American Avocet taken near Regina (Kodachrome by Elmer Fox). Price $\$ 1.00$.

Order cards and calendars from Margaret Belcher, Secretary, Blue Jay, Regina College, Regina. 